\title{
Design of Cooling and Air Flow System Using NDLC Method Based on TIA-942 Standards in Data Center at CV Media Smart Semarang
}

\author{
Septian Sony Hermawan ${ }^{1}$, Rd Rohmat Saedudin ${ }^{2}$
}

${ }^{1,2}$ School of Industrial and System Engineering, Telkom University

\begin{tabular}{l} 
Article Info \\
\hline Article history: \\
Received Feb 19, 2020 \\
Revised Mar 03, 2020 \\
Accepted Mar 28, 2020 \\
\hline
\end{tabular}

Keywords:

Data Center

Cooling System

Air Flow

TIA-942 Standard

NDLC Method

\begin{abstract}
CV Media Smart is a company that involved in the procurement of IT tools in schools and offices. With wide range coverage of schools and companies, CV Media Smart want to add more business process, therefore data center is needed to support existing and added later business process. The focus of this research is on cooling system and air flow. To support this research, NDLC (Network Development Life Cycle) is used as research method. NDLC is a method that depend on development process, like design of business process and infrastructure design. The reason why this research is using NDLC method is because NDLC is method that depend on development process. The standard that used in this research is TIA-942. Result of this research is a design of data center that already meet TIA-942 standard tier 1.
\end{abstract}

This is an open access article under the CC BY-SA license.

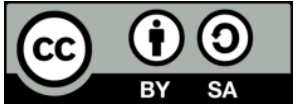

\section{Corresponding Author:}

Septian Sony Hermawan,

School of Industrial and System Engineering,

Telkom University

Email: septiansony009@gmail.com

\section{INTRODUCTION}

Data center is a facility that is used to place computer systems and related components, such as telecommunications systems and data storage [1]. These facilities usually include power supplies, environmental controls (eg air conditioning, ventilation), fire suppression devices, and physical security devices [2]. Data center is expected to support the business processes of a company or organization, currently many companies or organizations have data centers to support the activities of the company or organization. Data center generally must be able to operate optimally, one of which is to maximize data center operating time. Therefore, one of the factors needed to maintain the device in the data center so that it can operate optimally is the cooling system and airflow. Water flow and cooling system aspects in the data center are very important, because the electronic devices in the data center room emit average heat, which if a data center does not have a good cooling system and air flow, the devices in the data center can experience overheating, overheating can reduce the ability of a device and if left unchecked can make a device damaged and operational data center can be disrupted, then the cooling system and air flow must be considered properly [2-5].

$\mathrm{CV}$ Media Smart is a company that is engaged as the process of procuring IT equipment at schools and offices. Due to a plan from CV Media Smart to design a data center to assist in the business process of procurement of IT tools and database leasing for private server online games. Based on this, this study aims to assist the design of CV Media Smart data center in the cooling 
system and air flow data center aspects. To get a data center design proposal that suits the needs of CV Media Smart, the TIA-942 standard is used. The TIA-942 standard has been approved by the Telecommunications Industry Association (TIA), the American National Standard Institute (ANSI), and more than 60 organizations in the telecommunications industry that have contributed to developing this standard include manufacturers, end-user consultants, and other organizations, $[7,8]$. There are 4 tiers in the design of data centers, each tier offers a different level of availability tailored to the needs of a data center. According to the TIA (Telecommunication Industry Association), the aspects of tier assessment in the data center can be grouped into 4 criteria, namely aspects of building architecture, electrical aspects, telecommunications aspects and mechanical aspects [9].

To support this research the method used is the Network Development Life Cycle (NDLC). NDLC is a method that depends on the development process such as business process design and infrastructure design. The reason this research uses the NDLC method is because the NDLC method depends on the development process. Based on this, this study aims to produce a proposed design of cooling systems and data center air flow according to the TIA-942 standard in order to provide data center recommendations for CV Media Smart.

\section{LITERATURE REVIEW}

\subsection{Data center}

Data center is known as a collection of servers or computer space [10]. From this understanding it can be concluded that Data Center is a room that contains a collection of servers that are used to store data, operate data, and manage data.

\subsection{TIA-942}

The Telecommunication Industry Association is an American national standard that sets minimum requirements for telecommunications infrastructure of data centers and computer rooms. The topology prepared in this standard is intended to be applicable in all types of data centers. TIA942 discusses procedures regarding network architecture, electrical design, file storage, backup and archiving, system redundancy, network access control and security, database management, web hosting, application hosting, and content distribution, environmental control, protection againts physical hazards (fire, flood, windstorm), and power management [10-11].

\section{RESEARCH METHOD}

Research Systematics is an explanation of things done during the research. This study uses the NDLC method with limitations at the analysis and design stages. Systematics of this research was made in the form of a flowchart, to make it easier to see the stages carried out during the study.

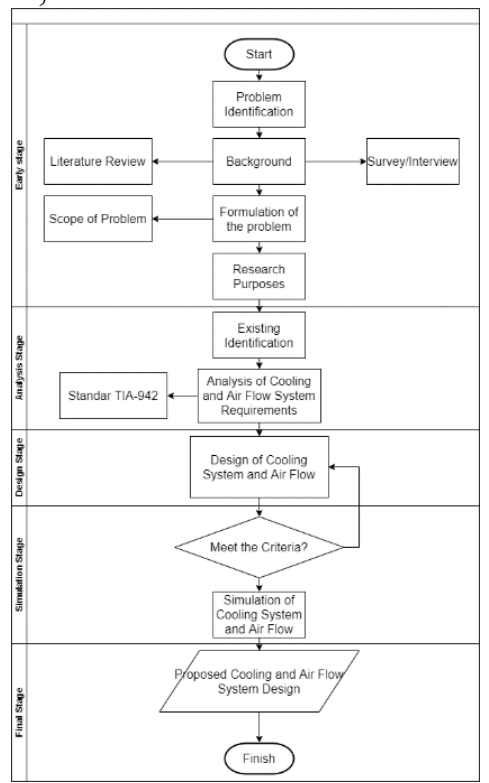

Figure 1. Systematics Research 


\section{ANALYSIS AND PROPOSED APPROACH}

\subsection{Existing condiition}

At this stage, comparing existing conditions with the criteria that must be met from the TIA-942 tier 1 standard.

Table 1. Current Conditions Based on TIA-942 Tier 1 Standards

\begin{tabular}{|c|c|c|c|c|}
\hline \multirow{2}{*}{ No. } & \multirow{2}{*}{ Parameter } & \multicolumn{3}{|c|}{ Tier 1} \\
\hline & & Required/Not & Existing & Information \\
\hline 1 & \multicolumn{4}{|c|}{ General } \\
\hline 1.1 & $\begin{array}{l}\text { Cabling, racks, cabinets and } \\
\text { pathways that meet TIA } \\
\text { standards }\end{array}$ & Required & $\begin{array}{l}\text { There are no cabling, } \\
\text { racks, cabinets, and } \\
\text { pathways that meet } \\
\text { TIA standards }\end{array}$ & $\begin{array}{l}\text { Not meet } \\
\text { tier } 1 \text { criteria }\end{array}$ \\
\hline 1.2 & $\begin{array}{l}\text { Routers and switches, have } \\
\text { a redundant power supply } \\
\text { and processor }\end{array}$ & No & $\begin{array}{l}\text { Not to use routers and } \\
\text { switches that have } \\
\text { redundant power } \\
\text { supply and processor }\end{array}$ & $\begin{array}{l}\text { Not required } \\
\text { in Tier } 1\end{array}$ \\
\hline 1.3 & Cooling System & Required & $\begin{array}{c}\text { Not using a cooling } \\
\text { system that meets TIA } \\
\text { standards }\end{array}$ & $\begin{array}{l}\text { Not meet } \\
\text { tier } 1 \text { criteria }\end{array}$ \\
\hline 1.4 & Raised floor & Optional & $\begin{array}{l}\text { Not yet implemented } \\
\text { raised floor }\end{array}$ & $\begin{array}{l}\text { Not meet } \\
\text { tier } 1 \text { criteria }\end{array}$ \\
\hline 1.5 & UPS and Generator & Required & $\begin{array}{c}\text { Don't have a UPS and } \\
\text { generator yet }\end{array}$ & $\begin{array}{l}\text { Not meet } \\
\text { tier } 1 \text { criteria }\end{array}$ \\
\hline 2 & \multicolumn{4}{|c|}{ Chilled Water System } \\
\hline 2.1 & $\begin{array}{l}\text { Indoor Terminal Air } \\
\text { Conditioning Units }\end{array}$ & Required & $\begin{array}{l}\text { Not using } \mathrm{AC} \text { without } \\
\text { redundant }\end{array}$ & $\begin{array}{l}\text { Not meet } \\
\text { tier } 1 \text { criteria }\end{array}$ \\
\hline 2.2 & $\begin{array}{l}\text { Humidity Control for a } \\
\text { computer room }\end{array}$ & Required & $\begin{array}{c}\text { There is no air } \\
\text { humidity regulator }\end{array}$ & $\begin{array}{l}\text { Not meet } \\
\text { tier } 1 \text { criteria }\end{array}$ \\
\hline 2.3 & $\begin{array}{l}\text { Electrical Service to } \\
\text { Mechanical Equipment }\end{array}$ & Required & $\begin{array}{c}\text { There is no electrical } \\
\text { service to the } \\
\text { equipment }\end{array}$ & $\begin{array}{l}\text { Not meet } \\
\text { tier } 1 \text { criteria }\end{array}$ \\
\hline 3 & \multicolumn{4}{|c|}{ Heat Rejection } \\
\hline 3.1 & Chilled Water System & Required & $\begin{array}{l}\text { Not using single path } \\
\text { cilled water system } \\
\text { and chilled water } \\
\text { pump without } \\
\text { redudant } \\
\text { There is no water- } \\
\text { cooled chiller without } \\
\text { redudant }\end{array}$ & $\begin{array}{l}\text { Not meet } \\
\text { tier } 1 \text { criteria }\end{array}$ \\
\hline 3.3 & Air-Cooled Chiller & Required & $\begin{array}{l}\text { There is no water- } \\
\text { cooled chiller without } \\
\text { redudant }\end{array}$ & $\begin{array}{l}\text { Not meet } \\
\text { tier } 1 \text { criteria }\end{array}$ \\
\hline 3.4 & Water-Cooled Chiller & Required & $\begin{array}{l}\text { Do not have cooling } \\
\text { towers without } \\
\text { redudant }\end{array}$ & $\begin{array}{l}\text { Not meet } \\
\text { tier } 1 \text { criteria }\end{array}$ \\
\hline 3.5 & Cooling Towers & Required & $\begin{array}{l}\text { Do not have a } \\
\text { condenser water } \\
\text { pumps without } \\
\text { redudant }\end{array}$ & $\begin{array}{l}\text { Not meet } \\
\text { tier } 1 \text { criteria }\end{array}$ \\
\hline 3.6 & Condenser Water Pumps & Required & $\begin{array}{l}\text { Not using single path } \\
\text { cilled water system } \\
\text { and chilled water } \\
\text { pump without } \\
\text { redudant }\end{array}$ & $\begin{array}{l}\text { Not meet } \\
\text { tier } 1 \text { criteria }\end{array}$ \\
\hline
\end{tabular}




\begin{tabular}{|c|l|l|c|l|}
\hline $\mathbf{4}$ & \multicolumn{4}{|c|}{ Air-Cooled System } \\
\hline 4.1 & $\begin{array}{l}\text { Indoor Terminal Air } \\
\text { Conditioning Units/ } \\
\text { Outdoor Condenser }\end{array}$ & Required & Has 1 AC in the room & $\begin{array}{l}\text { Not meet } \\
\text { tier 1 criteria }\end{array}$ \\
\hline 4.2 & $\begin{array}{l}\text { Humidity Control for a } \\
\text { computer room }\end{array}$ & Required & $\begin{array}{c}\text { Don't have humidity } \\
\text { control }\end{array}$ & $\begin{array}{l}\text { Not meet } \\
\text { tier 1 criteria }\end{array}$ \\
\hline 4.3 & $\begin{array}{l}\text { Electrical Service to } \\
\text { Mechanical Equipment }\end{array}$ & Required & $\begin{array}{c}\text { Only has 1 access to } \\
\text { electricity for AC } \\
\text { devices }\end{array}$ & $\begin{array}{l}\text { Not meet } \\
\text { tier 1 criteria }\end{array}$ \\
\hline $\mathbf{5}$ & \multicolumn{4}{|c|}{ HVAC Control System } \\
\hline 5.1 & HVAC Control System & Required & $\begin{array}{c}\text { There is no system } \\
\text { control }\end{array}$ & $\begin{array}{l}\text { Not meet } \\
\text { tier 1 criteria }\end{array}$ \\
\hline 5.2 & $\begin{array}{l}\text { Power Source to HVAC } \\
\text { Control System }\end{array}$ & Required & $\begin{array}{c}\text { Don't have access to } \\
\text { electricity }\end{array}$ & $\begin{array}{l}\text { Not meet } \\
\text { tier 1 criteria }\end{array}$ \\
\hline
\end{tabular}

\subsection{Proposed Data Center Design}

In the existing conditions there is no floor plan or design for data center placement, it is necessary to design a data center in accordance with TIA-942 tier 1 standards.

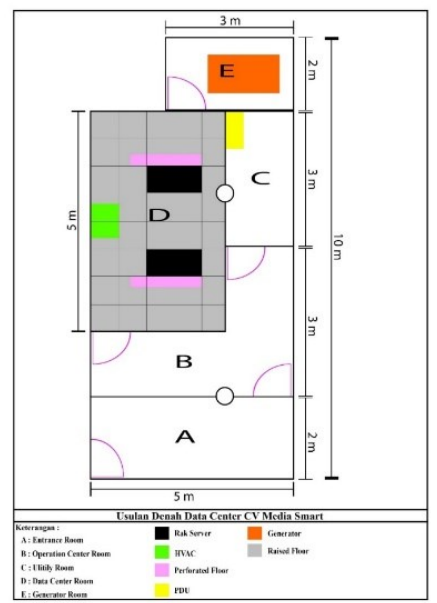

Figure 2. Proposed Plan for Data Center Room

\subsection{Proposed Cooling System}

To apply a cooling system in a data center room a method called Row Oriented Cooling is used. Row oriented cooling is a method that allows hot air and cold air to have separate grooves, because all sides that emit heat will be confronted and emit heat together, then the other side will be given cold air from the HVAC so that cold air enters and pushes hot air out of a device that emits heat. To be able to support the row oriented cooling method, a device that can emit cold air and absorb hot air must be used, therefore a cooler called HVAC is used, because this HVAC can remove the dinign air through the raised floor and absorb the hot air through the top, so there will be no meeting of cold and hot air.

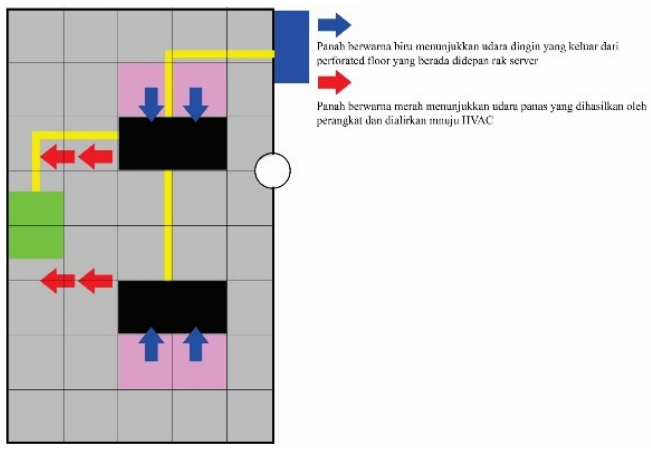

Figure 3. Air Flow Plan and Device Placement 
Based on Figure 3 the placement of the server rack and the HVAC device is intended so that the hot air generated by the device placed on the server rack, can be immediately absorbed by the HVAC device. The part that produces hot air is the back of the server rack, while the part that is flowed with cold air from the HVAC is the front of the server rack. In order for the cool air to be flowed from the HVAC to reach the server rack, a perforated tile is needed at the front of the server rack.

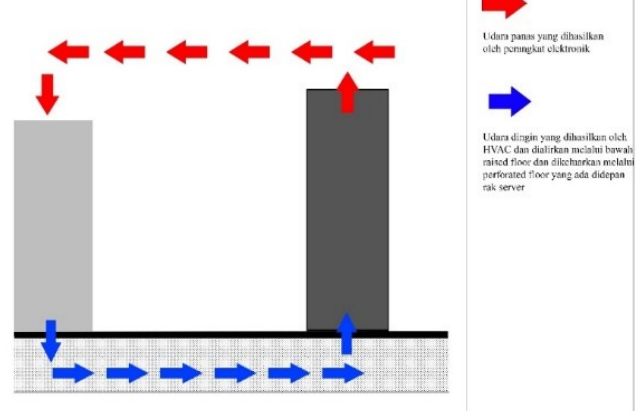

Figure 4. Air Flow Plan and Device Placement

Figure 4 shows how the cold air generated by the HVAC device is flowed to the server rack through the bottom of the raised floor, which then air will come out from the bottom of the raised floor through perforated tiles that have been installed on the front of the server rack. And the hot air generated by the device installed on the server rack, will be directly sucked up by the HVAC device.

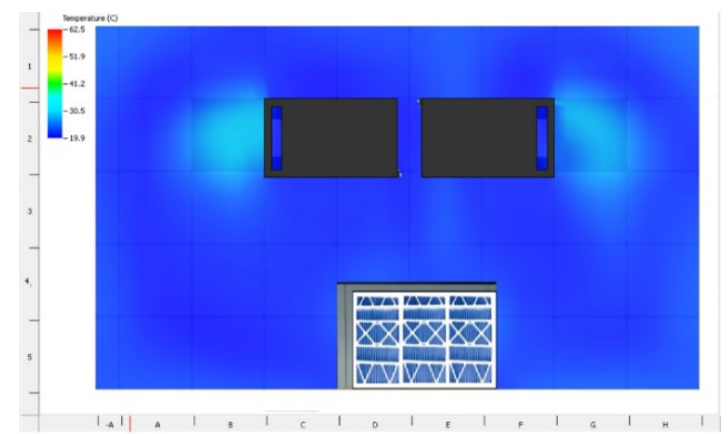

Figure 5. Air Flow Data Center Room

From Figure 5 it can be seen that the area that produces heat is on the front and back of the server rack with temperatures between 25 to $28^{\circ} \mathrm{C}$.

\subsection{Perforated Tiles and Raised Floor Design}

According to Figure 6, raised floors are installed to fill the room, except in front of the server rack because a perforated floor will be installed.

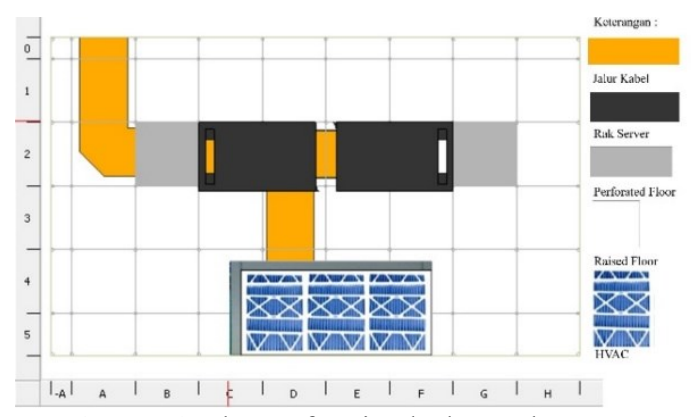

Figure 6. Plans of Raised Floor Placement 
There are two types of raised floor panels, namely HPL (High Pressure Laminate) and Bare, the type that is suitable for use is the type of HPL, because raised foor of this type has been coated with anti-static and scratch-resistant material. While the BARE type does not yet have an anti-static and scratch-resistant coating, and needs to be finished finishing by adding carpet tiles that can disturb the room temperature later.

\section{CONCLUSION}

Based on this research, it can be concluded to design a cooling and air flow system design in CV Media Smart data center as follows. At the stage of identification of room conditions based on the TIA-942 standard, available rooms do not meet the data center requirements. Because the data center to be created has a small scale, the use of tier 1 is sufficient to meet the needs of the data center. At the design stage, the design provided is based on the TIA-942 tier 1 standard, and the cooling device uses HVAC. The proposed data center room uses raised floors and perforated tiles.

\section{REFERENCES}

[1] M. Al-Fares, A. Loukissas, and A. Vahdat, "A scalable, commodity data center network architecture," Proceedings of the ACM SIGCOMM 2008 conference on Data communication SIGCOMM 08, 2008.

[2] E. Pakbaznia and M. Pedram, "Minimizing data center cooling and server power costs," Proceedings of the 14th ACM/IEEE international symposium on Low power electronics and design - ISLPED 09, 2009.

[3] M. Wiboonrat, "Risk anatomy of data center power distribution systems," 2008 IEEE International Conference on Sustainable Energy Technologies, 2008.

[4] D. M. Gomes, P. T. Endo, G. Goncalves, D. Rosendo, G. L. Santos, J. Kelner, D. Sadok, and M. Mahloo, "Evaluating the cooling subsystem availability on a Cloud data center," 2017 IEEE Symposium on Computers and Communications (ISCC), 2017.

[5] M. Wiboonrat, "Data center design of optimal reliable systems," 2011 IEEE International Conference on Quality and Reliability, 2011.

[6] H. Ye, Z. Song, and Q. Sun, "Design of green data center deployment model based on cloud computing and TIA942 heat dissipation standard," 2014 IEEE Workshop on Electronics, Computer and Applications, 2014.

[7] Greenberg, Steve, et al. "Best practices for data centers: Lessons learned from benchmarking 22 data centers." Proceedings of the ACEEE Summer Study on Energy Efficiency in Buildings in Asilomar, CA. ACEEE, August 3 (2006): 76-87.

[8] Dunlap, K., \& Rasmussen, N. (2006). The Advantage of Row and Rack Oriented Cooling Architectures for Data Center. American Power Conversion.

[9] Telecommunication Industri Association. (2005). Telecommunication Insfrastucture Standard for Data Center. Arlington: TELECOMMUNICATIONS INDUSTRY ASSOCIATION.

[10] Bullock, M. (2009). Data Center Defintion Solutions. Diambil kembali dari http://www.cio.com/article/2425545/data-center/data-center-definitionand-solutions.html

[11] H. I. Bahari and S. S. M. Shariff, "Review on data center issues and challenges: Towards the Green Data Center," 2016 6th IEEE International Conference on Control System, Computing and Engineering (ICCSCE), 2016. 